\title{
Assessment of Entrepreneurship Skills Needs of Small-Scale Farmers in Akpabuyo Local Government Area of Cross Rivers State, Nigeria
}

\author{
Okpodu Victor* \\ Department of Rural Development and Gender Issues, \\ Agriculture and Rural Management Training Institute, ARMTI \\ P.M.B 1343, Ilorin - Kwara State, Nigeria \\ Dr. Oladunni Olufemi \\ Agriculture and Rural Management Training Institute, ARMTI \\ P.M.B 1343, Ilorin - Kwara State, Nigeria \\ Awoyemi Samson \\ Department of Training Technology, Agriculture \\ and Rural Management Training Institute, ARMTI. \\ P.M.B 1343, Ilorin - Kwara State, Nigeria
}

\begin{abstract}
Specifically, this study assessed the effects of socioeconomic characteristics on entrepreneurship skills of the farmers in the study area. A total of 104 farmers were randomly selected from ten communities in Akpabuyo local government area. Data collected were analyzed using descriptive statistics, logistic regression and correlation analysis. The result from the study shows that age (114.183) and household sizes (36.709) are significant socioeconomic variables that positively enhances the entrepreneurship skills of the farmers. Other socioeconomic variables that were significant but contributed inversely includes marital status $(-81.153)$, sex $(-37.035)$, education $(-38.655)$ and income $(-36.091)$. Also, this result was further subjected to correlation analysis to show how the socio economic variables relate with the entrepreneurship farming skills. The result shows that age was significant with $0.3249^{*}$ and $0.3417^{*}$ at enhancing the farmers skills to recognize business opportunities in the environments and networking with other business partners. The study further reveals that education was significant with $0.3127^{*}$ at enhancing farmers skills to recognize business opportunities, however, as the farmers level of education advances inversely by $-0.3193^{*}$ the farmers records a drop in networking skills. Furthermore, result indicates that farm sizes recorded $-0.4452^{*}$ for farmers skills at recognizing business opportunities in their environments. In summary, the findings reveals that the farmers are not innovative and therefore, lack the drive that is usually associated with an entrepreneurial spirit. Consequently, it is recommended that in promoting entrepreneurship development of farmers there is need to focus more on entrepreneurship farming by paying special attention in developing the entrepreneurial spirit of both farmers and extension agents.
\end{abstract}

Keywords: Entrepreneurship, Skill Needs, Small-Scale Farmers

DOI: $10.7176 / \mathrm{JESD} / 11-6-03$

Publication date:March $31^{\text {st }} 2020$

\subsection{Introduction}

Agriculture remains the bedrock of the rural economy in most developing countries. Countries like Nigeria are no exception to this, more so as nature has endowed her different agro-ecological zones with enormous agro entrepreneurship opportunities for agribusinesses to thrive and contribute significantly towards improving the socio-economic wellbeing of the rural people. Such, is the case of Akpabuyo Local Government Area which is predominantly an agrarian environment, and it is known as the Food Basket of Cross River State. The indigenes are predominantly into farming and inland fishing, and thus major in producing cassava, cocoyam, kola nut, coconut, oil palm produce and sea foods. This provides the Local Government Council to focus her agricultural policy on boosting goods and crop production, as well as encourage foreign investors to establish agro allied industries to supplement the existing ones.

Developing a competitive and sustainable agribusiness sector requires small scale farmers adopting the entrepreneurship skills as a key factor to the survival of their farming enterprises. Invariably, through agripreneurship skill application, the rural potentials will be efficiently utilised such that farm produce will become competitive at the ever-changing and increasingly complex global markets. However, questions have been raised overtime if small scale farmers possess the requisite to become entrepreneurs? Observation shows that the Nigerian farming system has over the years been criticised as unattractive, uneconomic, and inadequate in innovativeness, which has led to low market competitiveness of her produce at the global level. FAO (2004) as reported by Oko- 
Isu et al (2014) attributed this to the fact that farming is not thought of as an agric-food enterprise capable of moving the economy forward. Hence, this study will be addressing the above problem by examining the following questions in the study area:

i. What is the relevance of entrepreneurship concept to farming as a business?

ii. What are the entrepreneurship skills relevant to farming in the study area?

iii. Which skill is entrepreneurial and why?

To reverse this trend, there is need to make our rural small scale farmers successful farmer-entrepreneurs with technical competency, coupled with innovativeness to operate in a complex and dynamic global environment. Thus, it is expected that the activities of farmer-entrepreneurs need to be: part of a larger collection of other actors along a given commodity value chain, respecting each other; and working together to make a whole food system work better and more profitable. Based on this assertion, this study seeks to assess how the farmers apply their entrepreneurial skill in producing output that are competitive with the market. Specifically, this study will:

i. examine how socio-economic characteristics affects the entrepreneurial skills of the farmers; and ii. assess the effects of socio-economic characteristics on entrepreneurship skills of the farmers.

Ho: The hypothesis suggests that there is no relationship between socioeconomic characteristics and the farmer performance at the market.

\subsection{Conceptual and Theoretical Review}

The perception of entrepreneurship involves generating and funding innovative ideas in order to make profit. The profit could be from the sales of various farm produce/product or services that were created by the idea. De Wolf and Schoorlemmer (2007) views about this concept, explains the processes involved in value creation within new or existing businesses. Nwankwo and Okeke (2017), however, broadened this definition to include the concept of bringing together the factors of production. Earlier definition according to Di-Masi (2008), as quoted by Nwankwo and Okeke, led others to question whether there was any unique entrepreneurial function or whether it was simply a form of management. Before now, theorist had upgraded this concept by adding innovation to the definition of entrepreneurship. This innovation could be process innovation, market innovation, product innovation, factor innovation, and even organizational innovation. Nevertheless, advanced definitions described entrepreneurship as involving the creation of new enterprises and that the entrepreneur is the founder. While entrepreneurship comprises of a person (the entrepreneur) and his or her activities and tasks, the entrepreneurial tasks and activities focus on starting, developing and continuing a profitable business. Invariably, an entrepreneur is someone who produces for the market. Kahan (2012), concludes that an entrepreneur is someone who is determine and creative in looking for opportunities to expand his market.

Hence, promoting entrepreneurship at the rural level most especially amongst small scale farmers, provides an enormous employment potential. In view of this assertion, Petrin (1994), opined that aside improving farm earnings; women see it as an employment opportunity that provides autonomy, independence and a reduced need for social support. From this view, Kulkarni and Narkhede (2016), asserted that entrepreneurship enhances economic growth, productivity, innovation, and job creation, and is a key aspect of economic dynamism. It can be assumed that entrepreneurship stands as a vehicle to improve the quality of life of a farmer, families and communities, and to sustain a healthy economy and environment.

However, the acceptance of entrepreneurship as a central development force by itself will not lead to rural development and the advancement of rural enterprises. What is needed in addition is an environment enabling entrepreneurship in rural areas. The existence of such an environment largely depends on policies promoting rural entrepreneurship. FAO (2015), reports that about two-thirds of the developing world's 3 billion rural people, live in about 475 million small farm households, working on land plots smaller than $2 \mathrm{ha}$. In another view, World Development Report (2016) found that 500 Million people farm on less than 2 ha of land worldwide, but mostly without providing documentation for this claim. In Africa, HLPE statistical data of year 2000 as reported in World Development report found that for a sample size of 14 African countries, $80 \%$ of farms are smaller than 2 ha in sizes. In general, these reports show that smallholder farming is the most prevalent form of farming in the world. Therefore, to create and develop a profitable farm business, requires that an entrepreneurial farmer has the initiative, drive, capacity and ability to take advantage of the opportunities embedded in their regions. In view of this, Machfoed (2004), views that entrepreneurship comprises of an innovator, independent thinker and a creative person who is capable of transforming opportunities into new ideas while at the same time managing and measuring risk. This is so, due to the complexity of agriculture and the perishability of its produce which makes it highly susceptible to deterioration if not properly managed. Hence, Priyanto (2008) as cited by Darmadji (2015), asserted that an entrepreneur need to show the attitude of an independent, vibrant, ever willing to take risk in order to achieve certain objective. Such a person must also be creative in addition to having the knowledge and skills associated with farming business. Thus, the sustainability of a farm enterprise depends on the innovativeness and proactive measures that guides the decision of a small scale farmer in producing for the market. FAO (2012), concludes that small scale farmers around the world are becoming more market oriented as they have learned to 
take calculated risks to open or create new markets for their products.

However, report shows that Smallholder farmers usually farm for one of four reasons:

- Exclusively for home consumption with no intention of producing any surpluses for the market.

- Mostly for home consumption, but, with the intention of selling surpluses on the market. These comprises of farmers who understand the value of farming for the market, but are limited by the availability of, labour, finance or market information.

- Partly for the market and partly for home consumption. These are farmers who recognizes the importance of the market options and are just starting out on the path towards developing profit-driven farming businesses.

- Exclusively for the market. These are farmers who farm basically to make profits and so, produce and serve the various market options.

Fundamentally, entrepreneurs must possess certain skills that will help them to excel. The report of ESoF team as reported in the European Union Rural Review (2011), identified the following interlinked skills for entrepreneurial

\begin{tabular}{|c|c|}
\hline $\begin{array}{l}\text { Entrepreneurship } \\
\text { Skills }\end{array}$ & Analysis \\
\hline Networking capability. & This involves the ability to use contacts to develop business ideas. \\
\hline Opportunity spotting. & $\begin{array}{l}\text { This refers to financial, economic, technical and social opportunities. These skills } \\
\text { enables a farm enterprise to improve its commercial status by been cost effective in } \\
\text { production, innovative production methods, identifying potential customers/clients, } \\
\text { starting a new market channel, and any other opportunity that will be relevant to the } \\
\text { farm enterprise. }\end{array}$ \\
\hline Strategic planning. & $\begin{array}{l}\text { Thus, the skills and qualities required by farmers depends on the following } \\
\text { conditions: } \\
\text { i. Production and Technical Skills. } \\
\text { ii. Management Skills. } \\
\text { iii. Exogenous factors around a business suggest that farmer requires risk } \\
\text { management skills, market skills, strategic planning skills, networking } \\
\text { skills, team work and leadership skills. } \\
\text { iv. Skill like qualities such as being ambitious, creative, innovative, flexible, } \\
\text { positive attitude, committed spirit e.t.c to taking risk }\end{array}$ \\
\hline
\end{tabular}

\subsection{Methodology}

3.1 Study Area

This study was carried out in Akpabuyo LGA of Cross River State. It is situated between latitude $4^{\circ} 5^{\prime}$ and $5^{\circ} 40^{\prime}$ and longitude $8^{\circ} 25^{\prime}$ and $8^{\circ} 32$ East. It lies within the vegetation of a tropical rainforest belt.

\subsection{Data Collection}

In this study, both primary and secondary sources of data were used. For the primary source, the data gathering instruments included quantitative methods. The quantitative data were collected using structured interview and questionnaire administration procedure, while the Secondary sources include information about the location of respondents from field extension agent of the Cross River State Agricultural Development Project (ADP).

\subsection{Sampling Method}

Farmers from each of the ten communities in the LGA who are in collaboration with the activities of the extension agents of ADP were randomly selected.

\subsection{Method of Data Analysis}

Data collected for this study were analyzed using descriptive and inferential statistics. The descriptive statistics include mean, frequency and percentages. The descriptive result is presented in tabular form to showcase mean, frequencies, and percentages of the various socio-economic characteristics of the respondents.

\subsubsection{Logistic Regression Model}

Logistic regression model was used for analyzing the The model is stated as follows;

$y_{i}=\log \frac{p i}{1-p i}=\beta_{0}+\beta_{1} X_{1}+\beta_{2} X_{2} \ldots \ldots \ldots \ldots \ldots \beta_{6} X_{6}+U$

Where

$\mathrm{Y}_{\mathrm{i}}$ is market Performance (Good market performance $=1$ and otherwise 0$)$

$\mathrm{X}_{1}=$ Age (years)

$\mathrm{X}_{2}=$ Marital Status

$\mathrm{X}_{3}=$ Sex (dummy) 
$\mathrm{X}_{4}=$ Household Size (number of individual living and eating together)

$\mathrm{X}_{5}=$ Educational Status

$\mathrm{X}_{6}=$ Source of Income

$\beta_{0}=$ Constant

In assessing the farm level performance, this study used 'Marketing' as farm level performance variable to determine the magnitude of the relationships with farmers' entrepreneurship skills.

In order to measure the market performance, farmers in the study area were asked to choose if actually their produce met with the customers' market requirements in terms of:

i. Timely delivery

ii. Reliability of transaction

iii. Produce meeting standard and specification of customers

The famers used several channels of marketing as follows:

i. Selling their produce on the farm;

ii. Taking their harvest to the closest spot market (I.e designated local market) for sale.

iii. Selling the harvest at urban market;

iv. Supplying processors;

v. Selling to Itinerate traders; and

vi. Selling to collectors

\subsection{Result and Discussion}

\subsection{Socio Economic Characteristics of the Respondents}

The socioeconomic characteristics of the respondents are presented in Table 1 . The result shows that $38.5 \%$ of the

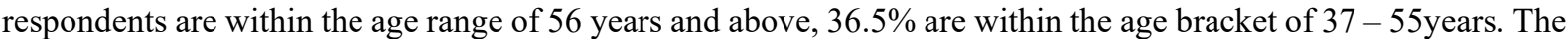
mean age of the farmers was 48years. The result further shows that, about $66.4 \%$ of the respondent are male while $33.6 \%$ of the respondent are female. This reveals that most of the agripreneurs in the study area are male. Meanwhile, result reveals that women are also active in farm business which is in consonance with the findings of Bolarinwa \& Chimezie (2016) who concluded that gender is no barrier to active involvement in farming. Also, the result shows that $75 \%$ of the respondents are married and about $64.4 \%$ of the respondents have a household size of $5-10$ persons per household. This finding agrees with the views of Eze. et al (2017) that marital status of farmers has a direct relationship on the household size and subsequently on the availability of family labour.

The result further reveals that $66 \%$ of the respondent are literate farmers with $42.7 \%$ having primary education, $15.5 \%$ with secondary school education and $1 \%$ are graduate. Meanwhile, $34.0 \%$ have no formal education. In addition, the result shows that most of the respondents $(62.1 \%)$ produced mostly for home consumption with intention to sell surpluses at the local market, and $31.1 \%$ farm partly for home and partly for the market. This reveals that most farmers are not truly entrepreneurs who are market oriented. These farmers engage basically in farming as a means to survival, but also including some economic activities. The result further explains that $58.6 \%$ of respondents earns their income from retail sales of farm produce and $26.3 \%$ primarily source their income through farming. This shows that while they farm for survival, farm produce are equally sourced from other farms to complement their own produce to be sold at the market.

\section{Factors Enhancing Entrepreneurial Skills Adopted by Farmers}

The result of the factors influencing the entrepreneurial skills adopted by farmers in meeting market requirement is presented in Table 2. The model summary shows log likelihood of 251.570 which is significant at pv. of $1 \%$ and this revealed the fitness of our model. COX and Snell $\mathrm{R}$ square and Nagelkerke $\mathrm{R}$ square values provides an indication of the amount of variation in the dependent variable explained by the model. In our case, the two values are 0.55 and 0.72 suggesting that between $55 \%$ and $72 \%$ of the variability is explained by the set of socio economy characteristic used in the model. Also, the result further revealed that all the selected socio-economic characteristics have the likelihood or probable of enhancing entrepreneurship skills adopted by farmers in meeting market requirements given that their coefficients is significant at P-value of 5\%.

- For every one unit of positive change in age, the log odds of performing at the market (versus non-market performance) increases by 114.183 . Thus, the farmers' ability to perform at the market increases with their age. Ability to meet market requirement can be said to increase with the farmers' age.

- As change occurs in marital status the log odds of meeting market requirement decreases by -81.153 . Farmers' who are singles perform better at the market than others. Which shows that farmers who are singles put in more efforts at understanding customers' requirements at the market.

- Every change in sex status the log odds of meeting market requirement decreases by -37.035 . It can be inferred that female farmers find it difficult to perform better at the market than the males.

- For a unit change in Household size the log odds of meeting market requirement increases by 36.709. This shows that as farmers get married and increases in household sizes, market performance also increases as 
more family members are engaged in meeting market requirements.

- For a one unit change in Education the log odds of meeting market requirement decreases by -38.655 . It implies that as the educational careers of the farmers' advances it shows a negative influence on their market performance.

- For a one unit change in sources of income the log odds of meeting market requirement decreases by -36.091. This shows that as a farmer earns more income, meeting market performance becomes an issue.

\subsection{Assessment of the level of entrepreneurship skills of the farmers}

Thompson et al (2000) as reported by Omoregie (2017) emphasized that entrepreneurship opportunity exits where there is a gap or a problem that needs to be solved innovatively. Hence, it is essential that an entrepreneur specializes in the art of opportunity identification by having a vision for the farm venture that matches his personal vision and values in a given environment. On this basis, the study identified the following as major business opportunities to the various farm enterprises in the study area:

i. $\quad$ Produce market. This include sales of vegetable, fruits, maize cobs, plantain e.t.c.

ii. $\quad$ Processing Activities. e.g. oil milling from palm fruit and kernel, fish and pig

iii. Input market. Sales of cassava stems, oil palm seedlings, animal droppings; and

However, when asked to assess themselves, response on Table 4 shows that $57.7 \%$ of the farmers says they are not skilled in recognizing and realizing business opportunities in their environment. The farmers claimed that they recognize opportunities only when there is an activity that is beneficial to their enterprise. Furthermore, we can say that the level of personal, passion and risk management skills required to launch and manage their businesses through turbulent times, are inadequate, irrespective of whether farm ventures are funded or not. Thus, suggesting that farmers should be willing to welcome support in the areas of farm business advisory and support services. Inadequacies of this skill according to the conclusion of Yadollah \& Sajady (2005) assert that such entrepreneurs require entrepreneurship education at not only identifying or recognize a market opportunity but able to generate a business idea based on environmental business opportunities to commit resources to pursue that opportunity while managing the prospect of risk.

Furthermore, networking and utilizing contacts involves different actors interacting amongst themselves to circulate relevant information and knowledge while at the same time different types of innovations are recognized or utilized. Despite the fact that $51 \%$ of the farmers are skilled at networking, $49 \%$ of the farmers not skilled should not be neglected as these number of people might be shut out of market information for input or where and how to sell their produce. Tepicta et al (2012) assert that through networking chain actors could make vital contributions to farmers' level of innovativeness. For example, processors and market requirements could influence farmers' innovativeness to integrate further in a given food value chain in order to take up a more competitive position at the market. Also, the table above further shows that a total of $67.3 \%$ of farmers are skilled at creating and evaluating business strategy. I,e. they can evaluate the market changes as it relates to demand and price change for certain produce based on their location. This skill shows that farmers are able to assess their resources before exploring on timely basis, any opportunity in their environment, even if there is demand for their produce and the selling price is attractive.

Table 5 present the result of correlation showing the relationship between selected socio-economic characteristics and the level of entrepreneur skills of the respondents. The result revealed that age is significant and positively related to level of skills the farmer have at recognizing business opportunity, networking and utilizing contacts. Also, it further reveals that as the farmer advances in age and years of engaging in agribusiness it shows positively overtime on its farm enterprise. The views of Schelske and Seidl (2002) as quoted by Gerard McElwee (2005) asserted that the success of entrepreneurship depends on a strong relationship between farmers, manufacturers, and consumers. Hence, this study explored three entrepreneurship skills affecting farmers' propensity to engage in farm entrepreneurship that could contribute to meeting market requirements.

In achieving the above, two empirical exercises were conducted. Firstly, logistic regression analysis was used to analyze the socio economic factors that contributed to enhancing farmers' performance at the market. Thus, the logistic analysis as stated on Table 3 identified six determinants that are significant in influencing the outcome measures in meeting market requirement. These determinants include Age, Marital Status, Sex, Household Size, Education and Income have $(\rho<0.005)$ significant contributions. Furthermore, the result from the analysis led us to investigate the relationship between these variables and farmers' assessment about their own level of entrepreneurship skills.

The result shows that as the respondent advances in age so is their contributory role at meeting market requirements also increases. This finding agrees with the assertion of Dragana et al (2017) who viewed that the effect of age is in line with modern studies that supports that entrepreneurship advances with age, and it is most strongly developed at middle years of 33-54. Also, the findings of Esiobu (2015) falls within the aforementioned age range by asserting that the average age of 42 years makes up the productive and economic age that plays a vital role in easy adoption of entrepreneurship skills in agribusiness. Furthermore, correlation coefficient on Table 
5 suggests the possible reason for farmers' performance at the market. I.e. as the farmer advances in age, so is their Skills at Recognising \& Realising Business Opportunities and Networking. Also. at old age, the farmers tend to rely more on years of experience in farming and marketing farm produce, because, then they should have an understanding of what to produce, when and how to market farm produce at the market. This also includes using contacts developed overtime to penetrate and develop a produce market. Agreeing with this finding, are the views of Edet \& Oguzie (2017) that reveals that entrepreneurial skills are acquired overtime and consequently age has an impact on entrepreneurship development. However, the negative relationship of age (-1.444) on entrepreneurship skills (Table 5), though not significant, suggests that the youths are showing more resilience at Creating and Evaluating Business Strategy which could be an implication of the high literacy level found amongst these age group.

The result further shows that the negative contribution of married farmers to meeting market requirements could be attributed to the fact that most farmers that are married might engage in farming exclusively for home consumption with no intention of producing surpluses for the market or alternatively, mostly for home consumption, but, with little intention of selling surpluses at the market. Kahan (2012) views explains the possible reason for the later choice, that though these farmers understand the value of farming for the market, but are limited by the availability of finance or market information. Hence, identifying potential customers, starting a new market channel, and any other opportunity that will be relevant to the farm enterprise may be of no concerns to them when compared to their family requirement. Therefore, the farmers' choices to risk family food requirement and thus produce primarily for home consumption with surpluses sold at the market or vice - versa depends on the farmers' willingness to take risk in supplying to the market.

Though the study reveals that farm entrepreneurship is a male dominated sector, however, the activities of the women might be more prominent in the marketing of surpluses. Therefore, the negative contribution of sex in meeting market requirements can be attributed to the low level of entrepreneurship skills amongst women. This might be because of certain cultural influences that restricts the activities of women to the household. If this so, it means women are more disadvantaged in entrepreneurship farming skills despite their contributory role to entrepreneurship development. Also, the negative significance of education from the regression result shows there is inadequate entrepreneurship skill amongst the respondents as it regards to Networking and Utilising Contacts. This could be attributed to the fact that despite the high literacy level recorded, farmers are finding it difficult to manage the exogenous factors around their farm enterprise. This suggests that farmers require skills in - risk management, marketing and networking. This statement is supported with the findings of Rezal et al (2011), who asserted that the negative relationship of formal education could be attributed to the fact that a higher level of formal education, coupled with more experience in agricultural activities and formal education in agriculture all give a lower probability of a farmer developing their entrepreneurial traits. This could happen because farmers who already have a high educational level may believe in their ability to set their own goals and business direction. However, correlation coefficient shows that with higher education, there is increased farmers' Skills at Recognising and Realising Business Opportunities, thus, agreeing with the assertion of Esiobu. (2015) who signified that farmers with adequate educational background show tendency to adopt innovations and skills in entrepreneurship development.

The correlation result showed two significant relationship in farm sizes. Firstly, a negative relationship inferred that as farmers increases their farm sizes, their market performance drops due to poor skills at Recognising \& Realising Business Opportunities. However, a positive relationship shows that when farmers have Skills at Creating and Evaluating Business Strategy their market performance increases with increase in farm size. These two contrasting findings are supported by the findings of McElwee (2005), who suggested that a great number of skills are required to run a farm business in a tightly constrained and regulated environment which acts as a significant barrier to entrepreneurial activity. However, farmers still prefer farming small farms because of its relative ease at accessing finance, technology, markets and react quicker to exogenous changes around. Also, the findings of Oluwale et al. (2016), inferred that irrespective of huge farmland, farmers prefer farming on little portions due to lack of input resources and high level of risk. These findings suggest that most farmers prefer farming on small scale for the market. This they can manage any risk factor that arises.

\subsection{Conclusion}

A lot is being said these days about farming as a business. The question then arises if our farmers can become 'entrepreneurs'? However, what is entrepreneurship? What does it take to be an entrepreneur? These and many more questions led this study to examine two socio - economic characteristics of the farmers in the study area. Firstly, it examined how socio-economic characteristics affects the entrepreneurial skills of the farmers; and then assessed the effects of socio-economic characteristics on entrepreneurship skills of the farmers based on their performance at the market. The findings of this study concludes that, while age and household sizes showed a direct relationship with farmers' performance at the market, marital status, sex, education and income presented an inverse relationship with farmers' performance at the market. It means that as the farmer advances in age and 
increases in household sizes, so is their skills at recognizing business opportunities, networking and skills at evaluating business strategies also increases. However, the inverse relationship in marital status, sex, education and income goes to show that they all share a common deficiency, which is inadequate skills at recognizing business opportunities and networking skills. The study further reveals that women are more disadvantaged in the acquisition of entrepreneurship farming skills. These findings suggests that farmers especially the youths are not innovative and therefore, lack the drive that is usually associated with an entrepreneurial spirit.

This study has shown that there is a skills gap in the sector and the skills that farmers need to develop with support from business advisors and relevant agencies include: networking skills, marketing skills, agribusiness risk assessment strategy, produce competitiveness and customer management strategy. Consequently, the followings recommendations are made:

i. Extensions/business facilitators to be better equipped to change farmers' perception from farming mostly for home consumption with the intention of selling surpluses at the market. Hence, the need for farmers to start seeing agriculture as a business, and as such, should be willing to take calculated risk;

ii. There is a clear indication that for the sector to be successful farmers need to be supported in their business endeavors. The need to introduce training workshop on entrepreneurship farming. There are two parts to entrepreneurship. Firstly, is the managerial skills required to start and manage a profitable farm enterprise. Secondly, it also involves developing the 'entrepreneurial spirit'. Hence, this new workshop will better equip extensions and farmers with the requisite skills and spirit of an entrepreneur.

iii. Innovativeness in entrepreneurship farming should be promoted most especially amongst youths and women in the area of recognising business opportunities, networking and evaluating business strategies.

\section{References}

1. Adaku Bridget Chidi Ezeibe, Ngozi Alice Okonkwo, Patience Ifeyinwa Opata, Oghenekevwe Edafiogho Dennis and A.N.Diogu. 2017. Analysis of Entrepreneurship Development in Agriculture Among Female Groundnut Farmers in Enugu State. European Journal of Business and Management www.iiste.org ISSN 2222-1905 (Paper) ISSN 2222-2839 (Online) Vol.9, No.32

2. David Kahan (2012). ENTREPRENEURSHIP in farming. Farm management extension guide. Food And Agriculture Organization Of The United Nations Rome 2012 http://www.fao.org/3/i3231e/i3231e.pdf

3. David Kahan, (2012). Entrepreneurship in farming. Farm management extension guide. Food and Agriculture Organization of the United Nations Rome 2012 http://www.fao.org/3/i3231e/i3231e.pdf

4. de Wolf, Pieter \& Herman Schoorlemmer (Eds.) (2007): Exploring the significance of Entrepreneurship in Agriculture. Research Institute of Organic Agriculture, Frick, Switzerland. http://orgprints.org/10915/1/dewolf-schorlemmer-2007-esof_000.pdf

5. Darmadji (2015). Entrepreneurship as New Approach to Support National Agriculture Development Program to Go Self Sufficient Food. International Conference on Food, Agriculture and Natural Resources, ICFANRes(2015).https://www.researchgate.net/publication/295833187_Entrepreneurship_as_New_Approach to_Support_National_Agriculture_Development_Program_to_Go_Self_Sufficient_Food

6. Dragana Radicic, Robert Bennett and Gill Newton, (2017). Portfolio entrepreneurship in farming: Empirical evidence from the 1881 census for England and Wales. Cambridge Group for the History of Population and Social Structure, Department of Geography, University of Cambridge, Downing Place, Cambridge CB2 3E, United Kingdom. https://www.researchgate.net/publication/319910673

7. Edet Joshua Udoh, Emem Bassey Inyang and Blessing Akudo Oguzie, (2017). Dimensions of Entrepreneurial Competencies of Agribusiness Managers in Niger Delta Region of Nigeria. Athens Journal of Business and Economics. Vol. 3, No. 4.

8. Eric Yaw Naminse and Jincai Zhuang, (2018). Does farmer entrepreneurship alleviate rural poverty in China? Evidence from Guangxi Province. https://www.ncbi.nlm.nih.gov/pmc/articles/PMC5875809/

9. Esiobu Mnaemeka Success, (2015). Analysis of Entrepreneurship Development in Agriculture among Arable Crop Farmers in Imo State, Nigeria. International Journal of African and Asian Studies ISSN 2409-6938 An International Peer-reviewed Journal Vol.7. https://www.researchgate.net/publication/272351994.

10. Eze.C. O, Chah. J.M, Uddin. I.O, Anugwa. I.J and Igbokwe. E.M (2017). Bio-Security Measures Employed by Poultry Farmers in Enugu State Nigeria. http://journal.aesonnigeria.org. vol. 21 (3) December 2017.

11. Food \& Agricultural Organisation of the United Nations. (2015). The economic lives of smallholder farmers. http://www.fao.org/3/a-i5251e.pdf; http://www.fao.org/family-farming/detail/en/c/385065/

12. FOOD AND AGRICULTURE ORGANIZATION OF THE UNITED NATIONS Rome, 2012. The State of Food \& Agriculture. http://www.fao.org/3/a-i3028e.pdf

13. Golnaz Rezai, Zainalabidin Mohamed, Mad Nasir Shamsudin (2011): Informal Education and Developing Entrepreneurial Skills among Farmers in Malaysia. World Academy of Science, Engineering and Technology International Journal of Humanities and Social Sciences Vol:5, No:7, 2011. https://waset.org/publications/1711/informal-education-and-developing-entrepreneurial-skills-among- 


\section{farmers-in-malaysia}

14. Kayode Omotayo Bolarinwa, C. Chimezie Okolocha, (2016). Entrepreneurial Skills Needed by Farm Youths for Enhanced Agricultural Productivity, Journal of economics and sustainable development Vol 7, No 16.

15. Machfoed, M., 2004. Entrepreneurship: A Contemporary Approach. Publishers and Printing Unit Academy of Management YKPN. Yogyakarta.

16. McElwee, Gerard. (2005). Developing entrepreneurial skills in Agriculture; A literature review on entrepreneurship in Agriculture. Public report of EU-project Developing Entrepreneurial skills of farmers. University of Lincoln, 2005. Available on www.esofarmers.org

17. Nwankwo .O. Francis, Chinwe S. Okeke. Rural entrepreneurship and rural development in Nigeria. Africa's Public Service Delivery \& Performance Review | Vol 5, No 1 | a152 | DOI: https://doi.org/10.4102/apsdpr.v5i1.152 | (C 2017 Francis O. Nwankwo, Chinwe S. Okeke | This work is licensed under CC Attribution 4.0

18. Oko-Isu Anthony, Nwachukwu Ifeanyi Ndubuto, Oteh Ukeh Ogbonnaya, Njoku Maria Etomchi. (2014). Analysis of Entrepreneurial Behavior among Cassava Farmers in Ebonyi State, Nigeria. International Journal of Agricultural Science, Research and Technology in Extension and Education Systems (IJASRT in EESs). Available online on: www.ijasrt.com. 2014: 4(2):69-74

19. Oluwale. B. A, Olaposi. T.O., Adelowo. C.M. and Akangbe. A., (2016). Factors Influencing Entrepreneurial Orientation of Smallholder Farmers in South-western Nigeria. FUTA Journal of Management and Technology. Vol.1, No. 2 December 2016.

20. Omoregie OK (2017). Entrepreneurial Opportunities and Financing Sources in a Developing Economy: A Focus on Nigeria. Lagos Business School, Pan-Atlantic University, Nigeria. file://C:/Users/User/Downloads/entrepreneurial-opportunities-and-financing-sources-in-adevelopingeconomy-a-focus-on-nigeria-2223-5833-1000314.pdf

21. Onyishi, C. N. (2011). Department of Sociology and Anthropology University of Nigeria, Nsukka

22. Petrin. T. (1994). Entrepreneurship and supporting institutions: an analytical approach. Entrepreneurship as an economic force in rural development ${ }^{l}$. Keynote paper presented at the Seventh FAO/REU International Rural Development Summer School, Herrsching, Germany, 8-14 September 1994. http://www.fao.org/3/W6882e/w6882e02.htm\#P44_8010

23. Pieter de Wolf, Pieter \& Herman Schoorlemmer (E-̄s.) (2007): Exploring the significance of Entrepreneurship in Agriculture. Research Institute of Organic Agriculture, Frick, Switzerland. http://orgprints.org/10915/1/dewolf-schorlemmer-2007-esof_000.pdf

24. Schelske, O., and Seidl, I., (2002), Anbau und Vermarktung alter Landsorten: Ein Fallbeispiel in: AGRARForschung 9 (10), pp. 434-439.

25. Shubhada Mohan Kulkarni and Parag Arun Narkhede (2016). Entrepreneurship and Rural development. https://www.researchgate.net/publication/313798944_Entrepreneurship_and_Rural_development

26. Tepicıa. M, Jacques H. Trienekensb, R. Hostec, and S.W.F. Omtad (2012). The Influence of Networking and Absorptive Capacity on the Innovativeness of Farmers in the Dutch Pork Sector. International Food and Agribusiness Management Review Volume 15, Issue 3, 2012. file://C:/Users/User/Downloads/20120012.pdf

27. World Development. (2916). The Number, Size, and Distribution of Farms, Smallholder Farms, and Family Farms Worldwide. Volume 87, November $\quad 2016, \quad$ Pages https://www.sciencedirect.com/science/article/pii/S0305750X15002703

28. Yadollah Mehralizadeh \& Sid Hossain Sajady. 2005. A study of factors related to successful and failure of entrepreneurs of small industrial business with emphasis on their level of education and training. Paper presented at the European Conference on Educational Research, University College Dublin, 7-10. http://www.leeds.ac.uk/educol/documents/143150.htm

29. Yaqoot, E. S., Wan Mohd Noor, W. S., \& Mohd Isa, M. F. (2017). Factors influencing traing Effectiveness: Evidence from public sector in Bahrain. Acta Universitatis Danubius. [Economica, 13(2)] 
Table 1: Distribution of respondents according to their socio economic characteristics $(\mathrm{N}=104)$

\begin{tabular}{|c|c|c|}
\hline Variables & Frequency & Percentage \\
\hline \multicolumn{3}{|l|}{$\overline{\text { Age }}$} \\
\hline $19-36$ & 19 & 19.6 \\
\hline $37-55$ & 38 & 39.2 \\
\hline 56 and above & 40 & 41.2 \\
\hline \multicolumn{3}{|l|}{ Sex } \\
\hline Male & 69 & 67.0 \\
\hline Female & 34 & 33.0 \\
\hline \multicolumn{3}{|l|}{ Marital status } \\
\hline Single & 15 & 16.3 \\
\hline Married & 73 & 79.3 \\
\hline Widower & 3 & 3.3 \\
\hline Separated & 1 & 1.1 \\
\hline \multicolumn{3}{|l|}{ Household Size } \\
\hline$<5$ & 17 & 20.0 \\
\hline $5-10$ & 57 & 67.1 \\
\hline$>10$ & 11 & 12.9 \\
\hline \multicolumn{3}{|l|}{ Educational Status } \\
\hline No Formal Education & 35 & 34.0 \\
\hline Quranic Education & 3 & 2.9 \\
\hline Adult Education & 4 & 3.9 \\
\hline Primary Education & 44 & 42.7 \\
\hline Secondary Education & 16 & 15.5 \\
\hline Tertiary Education & 1 & 1.0 \\
\hline \multicolumn{3}{|c|}{ Reasons for Engaging in Farm Enterprise } \\
\hline Exclusively for Home Consumption & 3 & 2.9 \\
\hline $\begin{array}{l}\text { Mostly for Home Consumption, } \\
\text { with Intention to Sell Surplus }\end{array}$ & 64 & 62.1 \\
\hline Partly for Home \& Partly for Market & 32 & 31.1 \\
\hline Exclusively for the Market & 4 & 3.9 \\
\hline \multicolumn{3}{|l|}{ Main Source of Income } \\
\hline Salary & 5 & 5.1 \\
\hline Sales of Farm Produce & 58 & 58.6 \\
\hline Civil Service & 1 & 1.0 \\
\hline Farming & 26 & 26.3 \\
\hline Trading & 9 & 9.1 \\
\hline Total & 104 & 100 \\
\hline
\end{tabular}

Sources: Field Survey data, 2019

Table 2: Factors influencing the entrepreneurship skills need of the farmers

\begin{tabular}{|c|c|c|c|}
\hline Socioeconomics Characteristics & B & S.E & P.value \\
\hline Age & 114.183 & 21780.677 & .000 \\
\hline Marital Status & -81.153 & 48236.262 & .000 \\
\hline Sex & -37.035 & 9970.527 & .000 \\
\hline Household Sizes & 36.709 & 18089.918 & .000 \\
\hline Education & -38.655 & 43325.908 & .000 \\
\hline Income & -36.091 & 13379.641 & .000 \\
\hline Constant & 23.767 & 57919.335 & .000 \\
\hline
\end{tabular}

\begin{tabular}{|l|r|r|r|}
\hline Step & -2 Log likelihood & Cox \& Snell R Square & Nagelkerke R Square \\
\hline 1 & $251.570^{\mathrm{a}}$ & .550 & .720 \\
\hline
\end{tabular}

a. Estimation terminated at iteration number 20 because parameter estimates changed by less than .001 Note: Source: Field survey 2019 
Table 3: Entrepreneurship Skills Assessments

\begin{tabular}{|l|c|c|c|}
\hline \multicolumn{1}{|c|}{ Entrepreneurship Skills } & Not Skilled & Moderately Skilled & Skilled \\
\hline Skilled in recognising \& Realising Business Opportunities & 60 & 17 & 27 \\
& $(57.7)$ & $(16.3)$ & $(26)$ \\
\hline Skilled in Networking \& Utilising Contacts & 51 & 17 & 36 \\
& $(49.0)$ & $(16.3)$ & $(34.6)$ \\
\hline Skills in creating \& evaluating Business Strategy & 34 & 23 & 47 \\
& $(32.7)$ & $(22.1)$ & $(45.2)$ \\
\hline
\end{tabular}

Note: Figure in parenthesis are percentages

Source: Field survey 2019

Table 4: Correlation Coefficient. Relationship between selected socio-economic characteristics and Level of Entrepreneurship Skills of the farmers

\begin{tabular}{|l|l|l|l|}
\hline Variables & $\begin{array}{l}\text { Skills at Recognising \& } \\
\text { Realising Business } \\
\text { Opportunities }\end{array}$ & $\begin{array}{l}\text { Skills in Networking and } \\
\text { Utilising Contacts }\end{array}$ & $\begin{array}{l}\text { Skills at Creating and } \\
\text { Evaluating Business } \\
\text { Strategy }\end{array}$ \\
\hline Age & $0.3249^{*}$ & $0.3417^{*}$ & -0.1444 \\
\hline Marital status & -0.2009 & -0.2348 & 0.2199 \\
\hline Sex & -0.0066 & 0.1222 & 0.1664 \\
\hline Household size & 0.1983 & 0.0962 & -0.0327 \\
\hline Education & $0.3127^{*}$ & $-0.3193^{*}$ & 0.1091 \\
\hline Income & -0.1340 & -0.2182 & 0.1522 \\
\hline Farm size & $-0.4452 *$ & -0.2606 & $0.3051^{*}$ \\
\hline
\end{tabular}

Note: * Significant at P-value of 5\%

Source: Field survey 2019 